
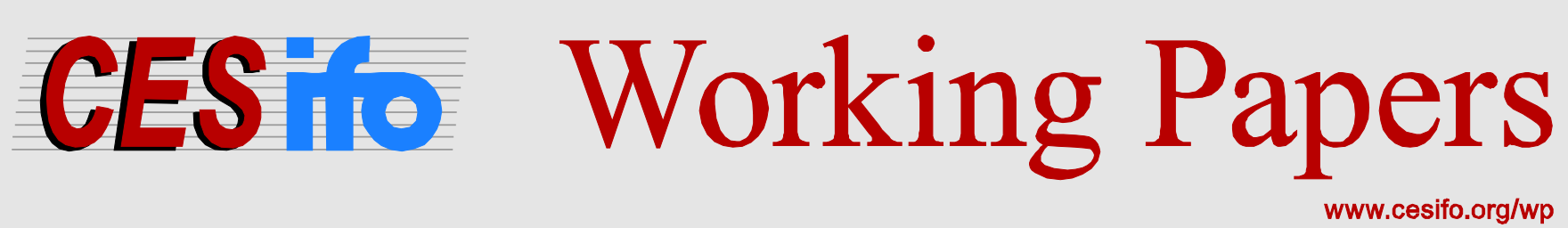

\title{
The Taxation of Internationally Portable Pensions: Fiscal Issues and Policy Options
}

\author{
Bernd Genser \\ Robert Holzmann
}

CESIFO WORKING PAPER NO. 5702

CATEgory 1: Public FinANCE

JANUARY 2016

An electronic version of the paper may be downloaded

- from the SSRN website:

- from the RePEc website:

- from the CESifo website:

wWw.SSRN.com

Www.RePEc.org

www.CESifo-group.org/wp 


\title{
The Taxation of Internationally Portable Pensions: Fiscal Issues and Policy Options
}

\begin{abstract}
Pension policy reforms across the world in recent decades are a reaction to the changing demographic and socioeconomic environment. While pension scheme redesign has received much attention, the tax treatment of contributions, returns, and benefits of retirement savings remains mostly unattended and the taxation of internationally portable pensions is terra incognita for economists. This paper focuses on the huge differences in old-age pension taxation within and across OECD countries and highlights fiscal equity and efficiency issues that emerge in a world of internationally mobile workers and pensioners. It highlights that pension taxation differs widely not only across countries but also across pension pillars within a country, creating savings and mobility distortions and fiscal equity problems at individual and country level. The paper offers explanations for this heterogeneity and proposes a switch from deferred taxation towards front-loaded taxation of retirement savings to meet the demographic challenges of a globalized world. Three policy options presented differ in the way taxes are paid, but all of them are claimed superior to single-country measures taken to uphold deferred pension taxation or to rely on renegotiations of bilateral double taxation treaties.
\end{abstract}

JEL-codes: H200, H240, H550.

Keywords: income tax reform, taxation of pensions, deferred income taxation, double taxation treaties.

\author{
Bernd Genser \\ University of Konstanz \\ Konstanz / Germany \\ bernd.genser@uni-konstanz.de
}

\author{
Robert Holzmann \\ Austrian Academy of Science \\ Vienna / Austria \\ robert.holzmann@gmail.com
}

December 23, 2015

A first version of the paper was presented at the CEPAR/CESifo Workshop on "Taxation of Pensions” in Munich in September 2015. We want to thank the participants for critical and helpful comments; any remaining errors and shortcomings are ours. 


\section{Introduction}

The recent developments in old-age pensions in OECD countries exhibit several characteristic features. First, old-age income consists of a mix of public, occupational, and private retirement incomes whose components have become more diversified and variable across countries. Second, to motivate employers and individuals to compensate for lower public generosity, countries have increased support for occupational and private retirement savings with various forms of tax preferences or direct subsidies. Third, mandatory as well as voluntary pension savings are typically subject to income tax but tax rules deviate from the general principle of comprehensive income taxation within and between countries. Lastly, a rising number of individuals are spending some part of their working life or retirement period abroad, a circumstance facilitated by improved portability of benefits between OECD countries but also within key migration corridors (e.g., France and Morocco; Germany and Turkey).

As a result of these developments, individuals increasingly receive pensions and other retirement income from national as well as cross-border entitlements and these disbursements differ in their tax treatment within and across countries. This gives rise to two main economic consequences: (i) taxation provokes efficiency losses due to planned tax arbitrage or unplanned exposure to tax distortions as individuals are either motivated to move between countries (or prevented from doing so) or to restructure their retirement income portfolio with little effect on overall retirement saving; and (ii) taxation infringes on equity principles at both the individual and country level. At the individual level, the application of different tax rules for retirement benefits and savings instruments by different countries violates horizontal equity and is a source of interpersonal fiscal unfairness. At the country level, different, inconsistent, and uncoordinated taxation rules for retirement income risk creating fiscal unfairness between countries and motivate tax competition.

A glimpse of the scope and dynamics of pensions paid abroad and received from abroad is provided for Germany in Table 1. The total number of pensioners living abroad on a German pension reached 1.7 million in 2013 (or 6.85 percent of all pensioners with a German pension). While the share of pensions paid to non-Germans living abroad is decreasing, the share paid to Germans living abroad is increasing. Non-German pensioners living in Germany may also receive a pension for pre-migration insurance periods in their country of origin (as do 1.1 million pensioners, or 4.21 percent of all pensioners with a German pension). Adding both together gives a total number of 2.8 million (or 11.1 percent) potential recipients of a cross-border pension. Yet these numbers of current pensioners reflect the labor mobility of the past and do not include the effects of higher pan-European labor mobility since the 1990s. Estimates for the European Union (EU) of the likely share of pensions paid abroad to the current workforce in the future arrive at some 15 to 25 percent (Holzmann 2015). 
Table 1: Recipients of statutory German pensions - in Germany or abroad

\begin{tabular}{|c|c|c|c|}
\hline $\begin{array}{l}\text { Number of pensioners in millions } \\
\text { (\% of total pensioners) }\end{array}$ & 2013 & 2010 & 2005 \\
\hline Total non-German pensioners & $2.562(100 \%)$ & $2.367(100 \%)$ & $2.032(100 \%)$ \\
\hline - living in Germany & $1.059(41.3 \%)$ & $0.944(39.9 \%)$ & $0.774(38.1 \%)$ \\
\hline - living outside Germany & $1.503(58.7 \%)$ & $1.423(60.1 \%)$ & $1.258(61.9 \%)$ \\
\hline Total German pensioners & $22.602(100 \%)$ & $22.646(100 \%)$ & $22.452(100 \%)$ \\
\hline - living outside Germany & $0.222(0.98 \%)$ & $0.206(0.91 \%)$ & $0.170(0.76 \%)$ \\
\hline Total pensioners & $25.164(100 \%)$ & $25.013(100 \%)$ & $22.484(100 \%)$ \\
\hline - living outside Germany & $1.725(6.85 \%)$ & $1.629(6.51 \%)$ & $1.427(5.83 \%)$ \\
\hline $\begin{array}{l}\text { - non-German pensioners } \\
\text { living in Germany }\end{array}$ & $1.059(4.21 \%)$ & $0.944(3.77 \%)$ & $0.774(3.44)$ \\
\hline $\begin{array}{l}\text { - potential recipients of } \\
\text { cross-border pensions }\end{array}$ & $2.784(11.1 \%)$ & $2.573(10.3 \%)$ & $2.201(9.8 \%)$ \\
\hline
\end{tabular}

Source: Eurostat Online Database (June 2015), own calculations.

The traditional instruments to address inequity issues in taxation are: (i) an appropriate income tax reform at the national level; and (ii) the renegotiation of double taxation treaties at the international level. We have strong doubts that these uni- and bilateral approaches are promising strategies to reduce the international complexity in income taxation of pensions and other retirement income. In particular, bilateral negotiations will be blocked by the fundamental antagonism that any assignment of taxing rights that supports interpersonal equity among migrating pensioners will generate inequity among national treasuries facing income tax revenue losses (in particular from exempted retirement savings in the pension accumulation phase).

On the other hand the international complexity in pension taxation reveals that normative economics does not offer clear advice on how to tax old-age income consistently and is even less informative on the taxation of internationally portable pensions. Yet to overcome lengthy and ineffective bilateral negotiations dominated by tax lawyers and to support a coordinated international approach on the taxation of internationally portable pensions, a convincing conceptual framework based on a good economic foundation is urgently needed. This is terra incognita, however.

Against this background, the paper is organized as follows. Section 2 offers an overview of the current state of taxing the main forms of old-age pensions/retirement savings in and between OECD countries. Section 3 explains why the taxation of retirement savings has become so complex in OECD countries and why characteristic differences prevail between countries in spite of the widely acknowledged principle of comprehensive income taxation. Section 4 argues that international coordination of pension taxation is desirable and explores three possible blueprints for tax regimes that replace the current dominant but not omnipresent system of deferred pension taxation with a 
front-loaded taxation system that can be combined with different payment patterns of income tax due over the pension cycle of contribution, return, and disbursement of pension wealth. Section 5 concludes.

\section{The State of Pension Taxation Within and Between OECD Countries}

In all OECD countries, old-age income from pensions and other retirement savings ${ }^{1}$ can be attributed to three tiers of pensions: statutory, occupational, and private. The quantitative significance of these three tiers varies markedly between countries and between social groups within a country. Moreover, remarkable differences characterize the tax treatment of these pension pillars within and between countries.

Before exploring the diversity and complexity of tax treatment, we offer some indicators on the importance of each pillar and the effects of taxation. Since no OECD- or EU-wide database is available to quantify the fiscal importance of the three tiers for pensioners across countries, we use the available coverage rates and gross replacement rates across the three pillars as well as the gross versus net replacement rates for the public pillar in EU member states and some other OECD countries (Table 2).

The data in Table 2 confirm that countries with high net replacement rates in statutory pension benefits make less use of occupational pensions, whereas countries with a broad enrolment in occupational pensions grant substantially lower net replacement rates in statutory pensions. This is visible in countries where the tradition of high statutory pensions is still the dominant social policy goal, such as Germany (DE), Austria (AT), France (FR), Italy (IT), Spain (ES), Portugal (PT), Finland (FI) and Slovenia (SI), whereas a pronounced multi-pillar strategy of statutory and occupational pensions can be found in Denmark (DK), Estonia (EE), Netherlands (NL), Sweden (SE), Ireland (IR), Norway (NO), and Switzerland (CH) as well as in Australia (AU), Canada (CA), and United States of America (US). This assessment is confirmed by the size of the pension funds as a percent of gross domestic product (GDP) across these countries (see OECD 2015; Towers Watson 2015). For the top 15 countries in the world, the size of pension assets amounted on average to 84.4 percent of GDP at the end of 2014.

\footnotetext{
${ }^{1}$ A pension benefit paid as a lifetime annuity from retirement till death is the main but not the only form of retirement income. It is dominant but not omnipresent in mandated schemes; was dominant in occupational schemes at the time of defined benefit (DB) schemes that were gradually replaced by DC schemes, often with no obligation to buy a lifetime annuity at a certain age; and hardly exists for voluntary savings. The remainder of this paper uses "pensions" and "retirement savings" interchangeably unless a differentiation is warranted.
} 
Table 2: Coverage and pension income replacement rates by pillar for OECD countries, 2015 (Replacement rates in brackets) ${ }^{1}$

\begin{tabular}{|l|c|c|c|l|c|c|c|}
\hline Country & Statutory & Occupational & Private & Country & Statutory & Occupational & Private \\
\hline AT & $100(76.6)$ & $17.7($ n.a. $)$ & 18.0 & LU & $100(87.1)$ & $3.0($ n.a.) & n.a. \\
\hline BE & $100(40.1)$ & $45.2($ n.a.) & 17.5 & NL & $100(29.5)$ & $91.0(61.1)$ & 28.3 \\
\hline BG & $100(84.3)$ & 98.0 & n.a. & PL & $100(48.8)$ & $94.0($ n.a.) & 4.7 \\
\hline CZ & $100(51.3)$ & 0 & 93.0 & PT & $100(54.7)$ & 3.3 (n.a.) & 5.1 \\
\hline DE & $100(57.1)$ & 22.5 (n.a.) & 40.0 & RO & $100(65.0)$ & n.a. & n.a. \\
\hline DK & $100(35.2)$ & n.a. & n.a. & SE & $100(55.6)$ & n.a.(22.6) & n.a. \\
\hline EE & $100(27.4)$ & $75.0(24.8)$ & 7.0 & SI & $100(39.2)$ & 47.0 (n.a.) & n.a. \\
\hline ES & $100(80.1)$ & 9.0 (n.a.) & 34.0 & SK & $100($ n.a.) & n.a. & n.a. \\
\hline FI & $100(58.8)$ & 6.4 (n.a.) & 19.1 & UK & $100(32.0)$ & $46.0($ n.a.) & n.a. \\
\hline FR & $100(58.8)$ & 16.5 (n.a.) & 5.4 & CH & $100(32.0)$ & $70.5(23.1)$ & n.a. \\
\hline GR & $100(53.9)$ & 0.2 (n.a.) & n.a. & NO & $100(45.7)$ & $68.1(6.8)$ & $23.2(11.3)$ \\
\hline HU & $100(76.3)$ & n.a. & 18.9 & AU & $100(13.6)$ & $68.5(38.7)$ & 19.9 \\
\hline IR & $100(36.7)$ & 31.0 (n.a.) & 12.0 & CA & $100(56.2)$ & $33.4(33.9)$ & 32.8 \\
\hline IT & $100($ n.a.) & 14.2 (n.a.) & n.a. & NZ & $100(40.6)$ & $77.1(14.1)$ & n.a. \\
\hline LI & $100(48.0)$ & 78.1 & n.a. & US & $100(38.3)$ & $41.6(37.8)$ & 22.0 \\
\hline LT & $100(47.0)$ & 89 (n.a.) & 11.6 & & & & \\
\hline
\end{tabular}

Source: Allianz International Pensions 2015.

Notes: ${ }^{1}$ These estimates refer to employees and not total population; ${ }^{2}$ n.a. stands for not available.

The net pension income replacement rates under the mandated scheme are determined by national pension law and also by national income tax law. The effects of income taxation on pension income can be approximated by comparing gross and net pension replacement rates; i.e., comparing the gross pension to the gross income before retirement and the corresponding gross values minus income taxes, respectively. ${ }^{2}$ If the income tax rates on earned income and pension benefits are the same, both replacement rates will coincide. If the income tax burden on pension benefits is lower than that on earned income before retirement, then the numerator of the gross replacement rate is reduced less than the denominator and the net pension replacement rate will be higher than the gross replacement rate. Table 3 shows this to be true for all OECD countries except DK and SE, which exhibit a negative replacement gap. Since OECD countries apply a progressive income tax schedule whose degree of progressivity shrinks with rising income, we would also expect the replacement gap to be large if the gross replacement rate is low, and to become smaller if the gross replacement rate rises. Table 3 shows that this pattern characterizes the majority of OECD countries, but noteworthy exceptions arise. Whereas in NZ and a couple of developing countries the replacement gap is low despite a gross replacement rate well below 50 percent, some Eastern EU countries and Turkey have a high replacement gap although the gross replacement rate is high as well.

Average replacement gaps emphasize the importance of income taxation on the average purchasing power of pensioners in a country, but they do not capture distribution effects across those pensioners. For disaggregated national replacement gaps, one would expect that progressive income taxation

\footnotetext{
${ }^{2}$ Replacement rates are a tricky concept that lends itself to many definitions. The same applies to the extent the net replacement rate covers all tax elements. This happens only if a pure back-loaded taxation is considered. When some front-loading tax elements are present, the net pension and contribution base need to be adjusted accordingly.
} 
would tend to favor high-income pensioners, whose gross replacement rates are usually lower than those of low-income pensioners. Empirically, however, these effects are fairly small. Besides preferential tax treatment of low-income pension earners, this finding may be related to changes in the composition of gross pension income along the income scale. For high-income pensioners, the share of statutory pension benefits will usually be smaller than the share of occupational and private pensions, which are typically taxed differently under national income tax law.

Table 3: Gross versus net pension replacement rates for median-income earners in OECD countries in 2014 (or nearest available year)

\begin{tabular}{|l|c|c|c|l|c|c|c|}
\hline \multicolumn{2}{|c|}{2014} & \multicolumn{2}{|c|}{ Replacement rates } & Difference & \multicolumn{2}{c|}{ Replacement rates } & Difference \\
\hline & Gross & Net & (net- gross) & & Net & Gross & (net-gross) \\
\hline Country & & & & Country & & & \\
\hline AR & 71.6 & 87.5 & 15.9 & IT & 69.5 & 79.7 & 10.2 \\
\hline AU & 44.5 & 58.0 & 13.5 & JP & 35.1 & 40.4 & 5.3 \\
\hline AT & 78.1 & 91.6 & 13.5 & KO & 39.3 & 45.0 & 5.7 \\
\hline BE & 46.6 & 60.9 & 14.3 & LU & 76.8 & 88.6 & 11.8 \\
\hline BR & 69.5 & 76.4 & 6.9 & ME & 25.6 & 28.4 & 2.8 \\
\hline CA & 32.6 & 42.9 & 10.3 & NL & 90.5 & 95.7 & 5.2 \\
\hline CL & 32.8 & 37.7 & 4.9 & NZ & 40.1 & 43.0 & 2.9 \\
\hline PRC & 74.0 & 80.5 & 6.5 & NO & 49.8 & 60.2 & 10.4 \\
\hline CZ & 49.0 & 63.8 & 14.8 & OECD & 52.7 & 63.0 & 10.3 \\
\hline DK & 67.8 & 66.4 & -1.4 & PL & 43.1 & 52.8 & 9.7 \\
\hline EE & 50.5 & 59.8 & 9.3 & PT & 73.8 & 89.5 & 15.7 \\
\hline EU28 & 59.0 & 70.9 & 11.9 & RU & 75.2 & 86.4 & 11.2 \\
\hline FI & 55.8 & 63.5 & 7.7 & SAR & 59.6 & 65.4 & 5.8 \\
\hline FR & 55.4 & 67.7 & 12.3 & SK & 62.1 & 80.6 & 18.5 \\
\hline DE & 37.5 & 50.0 & 12.5 & SI & 38.4 & 57.4 & 19 \\
\hline GR & 46.2 & 54.1 & 7.9 & SA & 10.5 & 11.8 & 1.3 \\
\hline HU & 58.7 & 89.6 & 30.9 & ES & 82.1 & 89.5 & 7.4 \\
\hline IC & 69.2 & 76.7 & 7.5 & SE & 64.4 & 63.6 & -0.8 \\
\hline IN & 96.5 & 109.7 & 13.2 & CH & 40.2 & 46.9 & 6.7 \\
\hline ID & 13.0 & 13.8 & 0.8 & TR & 75.7 & 104.8 & 29.1 \\
\hline IR & 34.7 & 42.2 & 7.5 & UK & 29.7 & 38.6 & 8.9 \\
\hline IS & 61.0 & 68.8 & 7.8 & US & 35.2 & 44.8 & 9.6 \\
\hline
\end{tabular}

Source: OECD 2015; OECD Data Pensions.

Before we explore the actual modalities of taxation of pensions/retirement savings within and between countries, an appropriate benchmark must be established. Tax policy makers in most countries agree that the basic guideline of their multiple tax system is the Schanz/Haig/Simons (SHS) principle of comprehensive income taxation. Perhaps not surprisingly, income taxation of old-age pensions in almost all OECD countries is characterized by a deviation from the SHS standard. This benchmark would require that individual entitlements to pension benefits accrued during citizens' working lives represent individual pension wealth whose economic value can be calculated. Annual increments of pension wealth increase individuals' ability to pay and should therefore be taxed under a comprehensive income tax. 
To compare national tax practices with the SHS benchmark, it is necessary to distinguish the three different forms of pension taxation, which correspond to different phases of pension wealth accumulation and disbursement. Phase 1 is the investment in pension wealth by individual contributions. Phase 2 is the return on individual pension wealth by capital market returns or by publicly guaranteed pension claims. Phase 3 is the disbursement of pension wealth when benefits are paid out. All three phases affect individual pension wealth and are relevant under a comprehensive income tax. The three phases overlap along an individual life-cycle since payment of contributions and returns on pension wealth occur in each year of income-earning and returns on pension wealth are incurred when pension benefits are paid out after retirement.

Technically comprehensive income taxation of pensions can be characterized by a T-T-E income tax, where $\mathrm{T}$ is the individual income tax rate and $\mathrm{E}$ indicates that an income flow is tax exempt. T-T-E implies that: (i) individual contributions are not deductible from the tax base because they increase pension wealth (phase 1); (ii) accruals to pension claims stemming from financial or notional returns during pension wealth-holding in the working and retirement years are also taxable (phase 2); and (iii) pension benefits that are paid out are neutral with respect to comprehensive income because they transform pension wealth into cash-holding and are therefore exempt (phase 3). Moreover we use t to indicate that a reduced tax rate $\mathrm{t}<\mathrm{T}$ is applied according to the income tax code.

A view of pension taxation over the pension wealth cycle reveals a very complex picture of deviations from the principle of comprehensive income taxation across OECD countries. No country in our sample applies T-T-E taxation to statutory pensions (Table 4); all of them provide tax relief either by deferring income taxation or by subjecting income to lower rates. Slovakia (SK) fully exempts income that is spent on pension savings and withdrawn after retirement.

Table 4: Income taxation of statutory pensions in OECD countries

\begin{tabular}{|l|l|l|}
\hline Tax regime & Country & Characterization of tax regime \\
\hline T-T-E & none & Comprehensive income taxation (CIT) \\
\hline t-E-T & FR, IR, CA, MT, NL, UK & Deferred CIT with double taxation relief \\
\hline E-E-T & $\begin{array}{l}\text { BE, DK, EE, FI, GR, IT, } \\
\text { LT, LU, AT, PL, PT, SE, } \\
\text { CH, SI, ES, CZ, CY }\end{array}$ & $\begin{array}{l}\text { Fisher/Kaldor expenditure tax, "Deferred income } \\
\text { taxation” }\end{array}$ \\
\hline T-E-E & DE, US & Prepaid expenditure tax \\
\hline t-E-t & LI & Partially deferred prepaid expenditure tax \\
\hline t-E-E & HU & Reduced prepaid expenditure tax \\
\hline E-E-E & SK & Full income tax exemption \\
\hline
\end{tabular}

Source: Wellisch et al. 2008 (table 2, p.27); IBFD 2015.

The picture for income taxation of occupational pensions is similar and exhibits an even greater scope of complexity (Table 5), although no country fully exempts occupational pensions from income tax. Two countries in our sample, Denmark (DK) and US, codify comprehensive income taxation, at least for some forms of occupational pensions. 
Table 5: Income taxation of occupational pensions in OECD countries

\begin{tabular}{|l|l|l|}
\hline Tax regime & Country & Characterization of tax regime \\
\hline T-T-E & DK, US & Comprehensive income tax \\
\hline t-T-t & IT, SE & CIT with partially deferred savings taxation \\
\hline T-E-T & CA, MT & CIT with deferred return taxation \\
\hline E-T-T & DK, DE, PT, US & CIT with deferred savings taxation \\
\hline t-E-T & $\begin{array}{l}\text { BE, EE, FI, FR, IR, LT, AT, } \\
\text { SI, UK, CY }\end{array}$ & Deferred CIT with double taxation relief \\
\hline E-E-T & $\begin{array}{l}\text { DE, GR, CA, LU, NL, AT, } \\
\text { CH, SI }\end{array}$ & $\begin{array}{l}\text { Fisher/Kaldor expenditure tax, deferred income } \\
\text { taxation }\end{array}$ \\
\hline T-E-E & PL & Prepaid expenditure tax \\
\hline t-E-t & $\begin{array}{l}\text { DE, LI, AT,PT, SK, ES, HU, } \\
\text { US }\end{array}$ & Partially deferred prepaid expenditure tax \\
\hline t-E-E & GR, LI, LU, AT, HU, CY & Reduced prepaid expenditure tax \\
\hline E-E-E & none & Full income tax exemption \\
\hline
\end{tabular}

Source: Wellisch et al. 2008 (table 3, p. 29); IBFD 2015.

Private pensions ${ }^{3}$ are granted particular tax preferences that differ for specific pension savings vehicles (Table 6). Surprisingly, none of the OECD countries in our sample offer expenditure taxation for private pension savings. Despite the complexity in private pension taxation, this finding seems to reflect a distinct dividing line in tax policy between taxing statutory and occupational pensions on the one hand and private pensions on the other.

Table 6: Income taxation of private pensions in OECD countries

\begin{tabular}{|l|l|l|}
\hline Tax regime & Country & Characterization of tax regime \\
\hline T-T-E & DK, SE & Comprehensive income taxation \\
\hline t-T-t & IT & Partially deferred CIT \\
\hline T-E-T & FR, MT & CIT with deferred return taxation \\
\hline E-T-T & DK & CIT with deferred savings taxation \\
\hline t-E-T & $\begin{array}{l}\text { BE, EE, FI, FR, IR, CA, LT, } \\
\text { LU, CH, SI, UK, CY }\end{array}$ & $\begin{array}{l}\text { CIT with deferred savings and partially } \\
\text { deferred savings taxation }\end{array}$ \\
\hline T-E-t & DE, FI, FR, MT, ES & $\begin{array}{l}\text { CIT with deferred preferential savings } \\
\text { taxation }\end{array}$ \\
\hline E-E-T & none & Fisher/Kaldor expenditure tax \\
\hline T-E-E & PO, US & Prepaid expenditure tax \\
\hline t-E-t & $\begin{array}{l}\text { DE, LT, LI, LU, NL, AT, PT, } \\
\text { CH, SK, ES, CZ, HU, US }\end{array}$ & Partially deferred prepaid expenditure tax \\
\hline t-E-E & GR, LT, LI, AT, HU, CY & Reduced prepaid expenditure tax \\
\hline
\end{tabular}

Source: Wellisch et al. 2008 (table 4, p.30); IBFD 2015.

The complexity of the tax treatment of pensions is further increased if pensions are accumulated or disbursed across borders. The avoidance of international double taxation of cross-border pensions is codified in bilateral double taxation treaties. Although these treaties usually follow the recommendations of the OECD model treaty, those signed exhibit differences for a specific residence

\footnotetext{
${ }^{3}$ Those private savings vehicles are typically considered as private pensions that have an explicit retirement income objective, are subject to specific regulations and supervision. and profit from deviations from the normal income tax law.
} 
country whose residents receive pensions from different source countries as well as differences when a specific source country pays out pensions to pensioners in different residence countries. Nevertheless, the general tendency in bilateral treaties is to assign tax competences in line with the residence principle. On the other hand, none of the treaties in our sample apply exemption with progression, viz. keeps the foreign pension untaxed but subjects the residential pensions to the hypothetical average tax rate of foreign plus residential retirement income.

A closer look at the bilateral network of double taxation treaties of Germany and Switzerland reveals three fundamental complexities of cross-border pension taxation, as both countries signed treaties that tax their residents' cross-border pension benefits differently depending on the source country and type of pension benefit. Thus a pensioner residing in Germany faces different tax rules for statutory, occupational, and private pension benefits based on whether he receives them from France, Italy, the Netherlands, Austria, Denmark, Belgium, or Canada.

Table 7: Tax assignment of cross-border pension benefits in German double taxation treaties

\begin{tabular}{|l|l|l|l|}
\hline Tax assignment & \multicolumn{1}{|c|}{ Statutory } & \multicolumn{1}{|c|}{ Occupational } & \multicolumn{1}{c|}{ Private } \\
\hline $\begin{array}{l}\text { Residence country } \\
\text { exclusively }\end{array}$ & CA, CH, CZ, EE, & AT, BE, CH, CZ, & AT, BE, CH, CZ, DK, \\
& $\begin{array}{l}\text { ES,FI, GR, HU, IR, } \\
\text { IT, LU, PT, SE, ES, FI, FR, GR, } \\
\text { SI,UK, US }\end{array}$ & $\begin{array}{l}\text { EU, IR, IT, LU, MT, FI, FR, GR, } \\
\text { NL, PL, SE, SI, UK, } \\
\text { US }\end{array}$ & $\begin{array}{l}\text { HU, IR, IT, LU, MT, PT, SE, SI, } \\
\text { UK, US }\end{array}$ \\
\hline $\begin{array}{l}\text { Source country } \\
\text { exclusively }\end{array}$ & $\begin{array}{l}\text { AT, BE, DK, FR, IT } \\
\text { (citizens), MT, NL, } \\
\text { PL, SE }\end{array}$ & FR (mandatory) & \\
\hline $\begin{array}{l}\text { Tax credit } \\
\text { in residence country }\end{array}$ & & CA, DK & CA, DK (rents) \\
\hline $\begin{array}{l}\text { Exemption with } \\
\text { progression }\end{array}$ & & & \\
\hline
\end{tabular}

Source: Wellisch et al. 2008.

Moreover, the double taxation treaties reveal that tax rules for pension benefits from the same source country (e.g. Canada) are codified differently in the treaty Canada-Germany and Canada-Switzerland. 
Table 8: Tax assignment of cross-border pension benefits in Swiss double taxation treaties

\begin{tabular}{|l|l|l|l|}
\hline Tax assignment & Statutory & Occupational & Private \\
\hline $\begin{array}{l}\text { Residence country } \\
\text { exclusively }\end{array}$ & $\begin{array}{l}\text { CA, CH, CZ, EE, } \\
\text { ES,FI, GR, HU, IR, } \\
\begin{array}{l}\text { IT, LU, PT, SE, } \\
\text { SI,UK, US }\end{array}\end{array}$ & $\begin{array}{l}\text { AT, BE, CH, CZ, EE, FR, GR, HU, IR, } \\
\text { IT, LU, MT, NL, PL, } \\
\text { SE, SI, UK, US }\end{array}$ & $\begin{array}{l}\text { AT, BE, CH, CZ, } \\
\text { GR, HU, IR, IT, LU, } \\
\text { MT, NL, PL, PT, } \\
\text { SE, SI, UK, US }\end{array}$ \\
\hline $\begin{array}{l}\text { Source country } \\
\text { exclusively }\end{array}$ & $\begin{array}{l}\text { AT, BE, DK, FR, IT } \\
\text { (citizens), MT, NL, } \\
\text { PL, SE }\end{array}$ & FR (mandatory) & \\
\hline $\begin{array}{l}\text { Tax credit } \\
\text { in residence country }\end{array}$ & & CA, DK & CA, DK (rents) \\
\hline $\begin{array}{l}\text { Exemption with } \\
\text { progression }\end{array}$ & & & \\
\hline
\end{tabular}

Source: Wellisch et al. 2008.

While it is true that bilateral negotiations between two treaty partners generate results that are determined by the initial positions of and the economic interdependencies between the two countries, it is amazing that bargaining for an equitable assignment of tax revenue has generated such a complex and uncoordinated multi-country pattern. This is particularly incomprehensible for OECD countries, which share basic principles of market economics, legality and political governance, and support the $\mathrm{UN}$, the OECD, the IMF, or the EU, all of which strive for a more transparent and coordinated international tax system. These countries are certainly aware that the status quo of international pension taxation is not fair and opens a playing field for strategic tax competition. The next section offers explanations for this disarray and provides analysis to guide the policy options described in section 4.

\section{Explaining the Diversity, Complexity, and Inconsistency of Approaches for Taxing Internationally Portable Pensions}

Hardly any other field in public finance or international economics exhibits such a level of diversity, complexity, and inconsistency within and across countries as the taxation of internationally portable pensions. Before offering possible policy solutions in design and implementation, it is useful to not only understand the likely reasons for such a conceptual and operational turmoil, but also to clarify them to establish a common understanding against which alternative policy solutions can be judged.

Four interrelated elements help explain the turmoil: (i) the diversity of ways to tax national pensions; (ii) the lack of fiscal fairness across countries due to double taxation treaties that do not address taxation of internationally portable pensions appropriately; (iii) the coordination dilemma of bilateral double taxation treaties; and (iv) the separation of social and fiscal policy responsibilities at the national and international level. As each explanatory element warrants a paper of its own, only the main arguments of each are sketched herein. 


\subsection{The diversity of taxation of national pensions - some explanations}

The two main explanations for the diversity of taxation of national pensions include: (i) a simple, traditional explanation that emphasizes the legal perspective on the differences in pension funding; and (ii) a more complex explanation that reflects the critical view of economists on consumptionoriented income taxation of retirement savings within a comprehensive income tax system. Under both explanations merit good considerations argue in favor of a preferential treatment of retirement savings

\section{(i) A traditional explanation: Unfunded and funded pensions are taxed differently}

In a traditional public finance view, statutory and certain forms of occupational pensions (working with book reserves or purely financed out of cash flow) are regarded as deferred labor income and hence are cash-flow taxed when pension benefits are paid out. Moreover employer and employee contributions are considered as vehicles of withholding labor income and are deducted from the labor income base. These pensions are therefore taxed E-E-T. In contrast, funded occupational pensions and in particular private (personal) pensions are regarded as capital income and taxed as comprehensive income upon accrual (i.e., T-T-E).

However, both funded occupational pensions and private retirement savings quite often are granted preferential tax treatment for various reasons; e.g., to counterbalance biased individual preferences, to reap positive externalities of higher retirement savings, or to give way to lobbying pressure from unions or the financial sector. Preferential treatment ranges from full or partial tax deferral of income spent on pension savings and of returns on accumulated pension wealth to reduced tax rates and full tax exemption of disbursements.

(ii) An alternative/supplementary explanation: The incomplete move from comprehensive income tax toward consumption-type income tax

The comprehensive income tax approach has been the worldwide guideline for rational income tax design for more than 100 years. The SHS principle of income taxation offers tax policy makers a number of advantages: (i) a broad definition of income allows collection of the required amount of tax revenue with a lower tax rate on taxable income; and (ii) application of the same tax rate to all forms of a taxpayer's annual income simplifies tax compliance, tax administration, and tax audits.

But for taxation of retirement income, the approach has a number of pitfalls that have contributed to its punctuation and partial demise: comprehensive income taxation according to a progressive schedule is equitable with respect to annual ability-to-pay but penalizes individuals with fluctuating annual income over their lifecycle. In particular, comprehensive income taxation distorts intertemporal consumption decisions as income spent on savings is subject to double taxation - once when saved and once when the returns on savings accrue. Economic recommendations to avoid these distortions by switching from comprehensive to consumption-oriented income (Fisher 1930; Kaldor 
1955) were largely ignored and rejected by tax policy makers and their advisers. On the other hand, tax policy was willing to deviate from the principle of comprehensive income taxation by deferring tax payment on unrealized capital returns and offering tax preferences on realized capital gains.

The theory of optimal tax policy in the 1970s brought an important change in the view on income or consumption as the superior tax base. Second-best tax policy models showed that political constraints and fundamental deviations from perfect market assumptions have important effects on optimal tax design that cannot be reduced to the decision of using either comprehensive income or personal consumption as the appropriate income tax base. A general result was that the principle of comprehensive income taxation, which requires labor and capital income to be taxed at the same rate, cannot be an optimal tax rule. The theoretical and institutional proposals in the 1970s suggested that a cash-flow approach that avoids taxation of the normal returns to capital is operationally feasible (Atkinson-Stiglitz 1976; IFS 1978; and US Treasury 1977).

Despite the conceptual advantages of expenditure taxation, no industrialized country in the world has ever tried to implement an expenditure tax to replace the traditional comprehensive income tax (Auerbach 2010). Yet with regard to retirement income, a limited and variable consumption-type income tax treatment of contributions, returns, and pay-outs has taken hold in most countries. ${ }^{4}$ Therefore, an expenditure tax treatment of retirement savings has become the typical benchmark for tax lawyers and pension economists (including Whitehouse 1999; Robalino et al. 2005; Huang 2008), although the SHS standard remains the guiding principle of income taxation.

\section{(iii) The varying scope and composition of tax preferences within countries}

Political motives for tax preferences vary between countries by the type of participation (mandated or voluntary) in pension schemes, the type of funding (non-financial or financial), the benefit type (DC or $\mathrm{DB}$ ), and socioeconomic characteristics. We claim that essentially three reasons explain the diversity of arrangements: First, the diversity of arrangements reflects differences in efficiency and equity concerns by governments across countries that may change over time. For example, the mostly unlimited deductibility of contributions to a mandated first- or second-pillar scheme is consistent with governments' objective of providing income replacement within pension floors and ceilings that are related to lower and upper limits of statutory contributions. For voluntary schemes - occupational and personal - the limits are typically much tighter and more variable over time. Second, not only are the objectives of government and individuals reflected in the tax treatment of retirement provisions, but so are those of the financial industry, which is very powerful and influential in most countries. Finally, changing tax preferences over time reflect the degree of fiscal pressure on government policy.

\footnotetext{
${ }^{4}$ Under standard model conditions the back-loading form of income taxation, E-E-T, is equivalent to the frontloading form, T-E-E, which therefore is regarded as a variant of expenditure taxation. This equivalence breaks down when excess returns on capital, progressive income taxes, or investment in risky assets are taken into account. Deviations from simple standard model assumptions usually create a rationale for further diversity in pension taxation (see Holzmann 2015).
} 
When retirement savings contracts become unsustainable but cannot be adjusted for old contractholders, one possibility to cope with this growing fiscal pressure is to change tax preferences for new contracts only. This need for transitional arrangements has contributed to tax systems' complexity.

\subsection{The lack of fiscal fairness across countries}

No general consistent rule in double taxation treaties defines how portable pensions should be taxed. This is certainly due to the OECD model convention treaty, whose article on pensions (Article 18) only deals with the taxation of pension benefits and assigns the right to tax them to the residence country. An escape clause allows the source country (Article 19/2) to retain the right to tax income from public pensions paid directly by public authorities or by public funds (unless the pensioner is a citizen of the residence country). Thus Article 18 recommends the residence principle on occupational and private pensions, but offers room for bilateral negotiations on taxing rights of statutory pensions.

But the model convention does not address pension taxation in the contribution and accumulation phases. Indeed, two problems arise that violate either equity between individuals or fiscal fairness across countries.

If a double taxation treaty assigns the right tax pension benefits to the residence country, as is typically the case for statutory and unfunded pensions, then pensioners will be overtaxed if they were already taxed in the source country during the contribution or accumulation phase, because the tax credit method can only be applied for income taxes paid on the identical tax base in the same year. If retirement savings and/or pension accumulation were tax exempt in the source country, then E-E-T taxation implies that all income tax on pensions goes to the residence country and the source country cannot recoup tax revenue losses due to exempting earned income spent on pension savings.

For nonresident civil servants, the OECD model convention allows pensions to be taxed in the country of disbursement. If this rule is included in a double taxation treaty, then the residence country has to forgo any income tax revenue from those pensions as well as from notional returns accrued after retirement.

Attempts by EU countries to unilaterally override fiscally unfair treaty rules and to recoup tax losses from pension tax preferences on occupational and private retirement savings upon migration were ruled as discriminatory and thus illegal by the European Court of Justice because they hamper free mobility (for details see Wellisch et al. 2008: 48ff).

Yet even the application of either front- or back-loaded consumption taxation (T-E-E or E-E-T) in both countries does not guarantee fiscal fairness between national treasuries. Table 9 presents the fiscal impact of different taxation principles in the source and residence country. The results range from no taxation to double taxation and reveal that interpersonal equity and fiscal fairness require a fundamental extension of the OECD model treaty. 
Table 9: Equity effects of tax principles and taxation assignment rules

\begin{tabular}{|l|l|l|}
\hline $\begin{array}{l}\text { Source country/ } \\
\text { Residence country }\end{array}$ & \multicolumn{1}{|c|}{ T-E-E } & \multicolumn{1}{c|}{ E-E-T } \\
\hline T-E-E & $\begin{array}{l}\text { I: Taxed once in source country } \\
\text { C: Tax revenue only in source } \\
\text { country }\end{array}$ & $\begin{array}{l}\text { I: Untaxed in both countries } \\
\text { C: No tax revenue in any country }\end{array}$ \\
\hline E-E-T & $\begin{array}{l}\text { I: Double taxation } \\
\text { C: Tax revenue in both } \\
\text { countries }\end{array}$ & $\begin{array}{l}\text { I: Taxed once in residence } \\
\text { country } \\
\text { C: Tax revenue only in residence } \\
\text { country }\end{array}$ \\
\hline
\end{tabular}

Source: Holzmann 2015.

Notes: I: Individual; C: Country.

Extended double taxation treaties seem particularly necessary to ensure that residence countries of pensioners are capable of providing to migrated retirees public goods and services that are typically age-dependent. On the other hand, it is desirable to curb strategic or opportunistic behavior by countries that voluntarily forgo taxing pensions of resident retirees to attract high-income pensioners and expect revenue through indirect taxation (such as Portugal).

\subsection{The coordination dilemma of bilateral double taxation treaties}

The chief instrument to address tax assignment issues among countries is a bilateral tax treaty. The prime objective of such a treaty is to avoid double taxation of natural or legal entities and increasingly to also limit strategic shifting of international income, particularly by multinational corporations (OECD 1913). Model treaties of the OECD and UN have led to a coordination of bilateral treaties, and six Scandinavian have signed a multilateral treaty, but the international network offers ample room for tax arbitrage and treaty shopping.

Besides the complexity and inconsistency of this international network, further problems arise as bilateral tax assignments leave national tax autonomy unchanged. Moreover, the international set of double taxation treaties triggers national tax reform measures that motivate strategic cross-border flows of tax bases and affect the international distribution of revenue. International tax revenue shifts reflect differences in national law (tax law, business law, pension law), the international structure of taxable units, and the strength of national tax administration and tax audits. Renegotiations of bilateral treaties are underway but multilateral coordination is poor because negotiations are not guided by overarching global principles but remain bilaterally focused, case-by-case agreements resulting from political bargaining over country-specific taxation topics. And renegotiation of double taxation treaties has proven to be too slow and casuistic to keep pace with rapid economic and demographic developments, although the OECD tries to revise its model treaty regularly.

Against this background, the bilateral treaty network is unlikely to help in reducing the diversity, complexity, and inconsistency in international taxation of pension income. First, no conceptual framework exists for how to integrate pension savings consistently into the OECD model treaty to mitigate the conflict between individual equity and inter-country fiscal fairness. Second, even if 
available, bilateral renegotiations of double taxation treaties would be a daunting (game-theoretical, multi-player) task given the room for bargaining for any pair of countries and the historical evidence on the duration of treaty renegotiations.

This suggests that a successful reform approach needs: (i) a conceptual framework for global pension taxation, supported by a major group of OECD members; (ii) the willingness to agree on a multilateral approach (e.g., at EU level); and (iii) some readiness to take up economic recommendations for a coordinated tax and pension policy at both the national level and that of international organizations.

\subsection{The separation of social and fiscal policy responsibility at national and international level}

The complaint about the lack of conceptual and administrative coordination between social and fiscal policy is not new and was recently reiterated in the Mirrlees Report (Mirrlees 2010).

In most countries, social policy and tax policy are assigned to different ministries with little coordination requirements or overall government guidance. Consequently, there is little readiness to look for economic tradeoffs in the use of the most appropriate tax and pension policy instruments as no gains exist from a parochial perspective. It remains to be seen if the Mirrlees Report's call for a concerted policy design that considers taxes and transfers simultaneously will be taken up in the UK.

The situation is similar at the EU Commission, where pension issues are split across a number of Directorates General (viz. the DGs Employment, Social Affairs and Inclusion; Financial Stability, Financial Services and Capital Markets Union; Economic and Financial Affairs) and separated from income taxation issues handled by the DG Taxation and Customs Union. From our experience, these DGs seem little motivated in engaging in cross-sectoral issues like equity and fiscal fairness of portable pensions in the internal market.

To the best of our knowledge, no international organization has used its mandate to explore, analyze, and guide pension design and pension taxation coherently at the national and international level. The International Labour Organization (ILO), historically in the forefront of social policy and retirement income considerations, has never dealt with tax issues. For many decades the IMF's Fiscal Affairs Department was the leader in taxation issues (at micro and macro level) and explored aging and pension issues at macro level, but the topics were never brought together, let alone in a trans-country perspective. The World Bank established itself as a leader in the international pension discussion with the 1994 publication “Averting the Pension Crisis” and the ensuing knowledge management on pension issues; but the World Bank was never strong on taxation issues and relied on country work, typically based on advice from IMF/FAD. Finally, the OECD combines both substantive pension work and taxation work under one roof but in different departments that often do not interact with one another, as their work programs are determined by committees that reflect national ministerial divisions (see above). 


\section{Old and New Policy Options to Streamline Taxing Internationally Portable Pensions}

One of the crucial liberties of internationalization is the free mobility of persons. Free mobility includes free access to national labor markets, to business activities, and to residency at retirement (as long as no social assistance type support is required).

Countries affected by immigration and emigration cope with various policy problems, one of which (and until now, not the most important) is the impact of migration on government revenue. Yet this topic is gaining importance by the day due to continued population aging and increasing migration flows.

E-E-T taxation of pension savings implies that each year the income tax base is reduced because earnings spent on old-age pension contributions or retained returns on pension wealth are deductible. In a closed economy, this income tax revenue loss is only temporary because income tax becomes due in later years when old-age pension income is paid out after retirement. If pensioners move to another country later in their working life or after retirement and are taxed according to the residence principle, the dominant rule in double taxation treaties, then the emigration country faces an actual revenue loss because migrants pay income tax to the tax authority of their new residence country. The typical tax policy measure of national governments is to make use of the room for source taxation of old-age pension income or to call for a revision of double taxation treaties that do not contain an appropriate source tax entitlement.

As highlighted in section 2, the current tax rules on old-age pension income to nonresidents differ widely. National rules differ: (i) with respect to statutory, occupational, and personal pensions; (ii) within and between countries according to the form of tax assessment (withholding at source or annual returns); (iii) according to the tax rate applied (progressive or specific income tax rate); and (iv) according to income tax preferences granted when contributions were made. Apart from the incredible complexity of tax rules, any extensive use of limited income tax liability in the source country runs the risk of international double taxation.

Efficiency and fairness in an old-age income tax regime can only be achieved if national and international objectives are considered simultaneously: First, a limited consumption-type treatment of retirement savings is justified inasmuch as contributions to mandatory pension systems are classified as "taxes" rather than savings. Second, consumption-type treatment of voluntary old-age retirement savings is often motivated to complement mandatory statutory and occupational pensions, which are regarded as insufficient to smooth intertemporal consumption in an aging society. Third, national as well as international double taxation of old-age pensions should be avoided. Fourth, revenue from income taxation over the lifecycle must be allocated fairly among involved states. Finally, pension taxation should not distort the migration decisions of individual workers or pensioners. Objectives 3 , 
4, and 5 are closely related to fundamental EU principles and suggest a coordinated European approach.

The problem of the current state of pension taxation is that the EU concentrated on objective 1 by recommending portability of pension entitlements and E-E-T taxation of statutory and mandatory occupational pensions, but left the solution of the other four objectives to member states. It is not surprising that member countries focused on national fiscal revenue by using or extending the room of existing double taxation treaties.

The key problem of fairness among national budgets is that under the current design, the initial income tax exemptions to migrants cannot be recouped by double taxation treaties' measures in a simple and transparent way. Negotiations on any form of source taxation of cross-border pension income suffer from a lack of transparency on previous income tax losses induced by preferential income tax treatment of pension savings. A temporary extension of unlimited income tax liability in the source country will only work if pensioners migrate after they start receiving pension payments. And codifying a reimbursement scheme by which residence countries compensate source countries for migration-induced income tax losses seems an impossible political venture under the current circumstances.

This section sketches one old and three new policy options to address the outlined objectives of taxing portable pensions. It starts with the policy option to revise the pension-relevant parts of existing double taxation treaties. This is followed by three policy options that build on each other as they have common features, including the same tax liability level but different payment dates: front-loaded pension taxation and payment; deferred payment of front-loaded pension tax liabilities; and split deferred payment of front-loaded pension tax labilities.

\subsection{Revising the international patchwork of double taxation treaties}

The current system of tax assignment of cross-border pension benefits may be characterized as a residence state system with certain special rules of limited or even full taxation of pension benefits in the source country. While it is true that double taxation of pension benefits is excluded if both countries apply E-E-T and the treaty requires tax crediting of source country taxes in the residence country, interpersonal equity cannot be achieved if pension savings are taxed in the source country when contributions are paid or when returns on pension wealth accrue. Individual double taxation can only be avoided if a treaty requires both countries to tax old-age pensions according to E-E-T, or if tax crediting is extended to prepaid income taxes. It seems very unlikely that treaty negotiations could lead to such amendments. Until now, it has never been the objective of treaties to require a reform of the national tax system and tax crediting has always been restricted to contemporaneous and legally identical source taxes that can be easily verified by the residence country's tax administration. 
Fiscal equity among treaty partners requires fair and appropriate assignment rules of pension benefit taxes. Basically this objective could be achieved by extending limited source tax assignments to all fiscally relevant schemes of cross-border pension benefits. Negotiations on these sharing rules will presumably be tedious and may fail because it is not possible to fully compensate revenue-losing countries. Moreover, negotiations will be hampered by the lack of transparent accounting mechanisms for fiscal revenue collected from pre-taxing pensions or alleged revenue losses from preferential income taxation of pension savings.

Bilateral treaty negotiations will be complicated furthermore by the fact that resident pensioners will receive pension benefits from different source countries and international portability of pension rights will produce cases whereby a country that suffered a tax revenue loss from preferential treatment of a pension saver is not the source country paying pension benefits and is therefore not a negotiation partner. A consistent solution to the double equity dilemma seems to require multilateral consent and we doubt that shifting this responsibility to bilateral treaty negotiations is a promising strategy.

\subsection{Intertemporally neutral front-loaded pension taxation ${ }^{5}$}

One promising approach to overcome the double equity dilemma of international pension taxation is to find a tax system that keeps the desirable properties of the Fisher/Kaldor deferred income tax but avoids complex revenue-sharing rules between source and residence countries to meet inter-country equity norms. The first new policy option is to replace the back-loaded E-E-T regime by an equivalent front-loaded system. By definition, front-loading avoids pension tax revenue losses when individuals migrate (as workers or retirees). Source and residence countries must implement front-loaded regimes that avoid double taxation of cross-country pensions, however.

Besides the once-only principle of taxing old-age pensions under an E-E-T deferred income tax, the other crucial economic property is intertemporal neutrality, viz. no distortion of lifetime consumption by a Fisher/Kaldor-type expenditure tax. This neutrality principle can also be fulfilled by a T-t-E income tax that exempts pension benefits withdrawn from accumulated pension wealth, but taxes income spent on pension savings when contributions are made and returns on pension wealth that exceed normal capital returns when they accrue. It must be admitted that equivalence (implying that E-E-T and T-t-E taxation are equal in present value terms and charge the same total tax burden on pensioners) only holds under a set of simplifying assumptions, viz. marginal income tax rates are constant over time and positive and negative income tax bases are treated symmetrically ${ }^{6,7}$ For both

\footnotetext{
${ }^{5}$ See Genser (2015) for details.

${ }^{6}$ The argument that equivalence breaks down for progressive income tax schedules because annual pension benefits will be lower than annual earned income and thus taxed at a lower rate is true but not well targeted. Progressive annual income taxes generate higher tax burdens whenever annual tax bases fluctuate over time and horizontal equity of lifetime income can only be achieved if the annual tax rate is constant over time. The assumption of an intertemporally constant tax rate should therefore not be assessed as an untenable simplification.
} 
income tax regimes, it is true that the present values of the tax burdens are lower than the corresponding tax burden under comprehensive income taxation with the same tax schedule.

Whereas E-E-T and T-t-E taxation are intertemporally neutral and amounts of taxes in present value terms are paid by the taxpayer and received by the tax authority in a closed economy, the situation changes in an open economy setting. National tax authorities are no longer indifferent between the two tax regimes as their revenue situation changes if taxpayers migrate.

The important advantage of applying T-t-E is that pensioners' migration will no longer distort international equity among treasuries. Pension benefits will be pre-taxed when contributions to pension systems are not deductible in the country of residence and no recouping of income tax relief is required to restore equity among countries' budgets. Double taxation can even be avoided if a residence country does not implement T-t-E but commits to exempt with progression cross-border, old-age pension benefits. If the residence country implements T-t-E, then it is also entitled to tax current excess returns on the migrant's pension wealth during retirement.

Another important point of discussion for every tax regime is administrative efficiency, which for a Tt-E tax depends crucially on a transparent and simple determination of excess returns on pension wealth. One attractive feature of T-t-E taxation is that its administration is largely in line with capital income taxation under a comprehensive income tax regime. Under both regimes, pension savings are not deductible, but a difference exists in the treatment of returns to pension wealth. While under a comprehensive income tax the total annual returns on pension wealth (denoted R) are taxable income, T-t-E requires that only excess returns are taxable. The appropriate calculation of excess returns requires a political decision on the rate of normal returns to pension wealth. A theoretical benchmark for such a rate is a risk-free interest rate marked up by an actuarial risk premium. Scandinavian countries use such a normal rate of return to run their dual income tax systems. Basically this rate must be fixed for each tax year and is binding for the taxpayer and the tax authority. Once this normal rate of return is fixed, the allowance (denoted A) for the amount of normal returns can be calculated for each taxpayer and the respective tax load $T^{*}(\mathrm{R}-\mathrm{A})$. Instead of using $(\mathrm{R}-\mathrm{A})$ as a component of the individual income tax base, T-t-E income taxation makes use of a simple transformation by defining a reduced income tax rate $t$, which applied to total returns $\mathrm{R}$ raises the same amount of income tax, $\mathrm{t} * \mathrm{R}$ $=\mathrm{T}^{*}(\mathrm{R}-\mathrm{A})$. $\mathrm{t}$ is thus defined by $\mathrm{t}=\mathrm{T}^{*}(1-\mathrm{R} / \mathrm{A})$. Allowance $\mathrm{A}$, or equivalently the tax rate decrement (T-t), reveals the "tax preference" that is implicitly incorporated in the EU recommendation to defer pension taxation rather than tax comprehensive income.

\footnotetext{
${ }^{7}$ In a world of certainty, excess returns above a normal market return reflect market imperfections. In a world exposed to uncertainty and risk, excess returns are those that exceed the normal market return and the appropriate risk premium. Therefore $t$ does not charge a tax burden on the risk premium and should be zero in a perfect capital market world.
} 
A second advantage in administering T-t-E in contrast to E-E-T is that no control of correct deductions for pension savings is required. Administration and compliance are greatly simplified, as old-age pension contributions and pension savings do not reduce the income tax base. Excess returns on pension wealth are calculated in the pension accounts of financial institutions that accumulate pension wealth or in pension agencies that administer notional DC schemes. Control of appropriate tax payment by tax authorities can thus focus on a small number of pension funds and other agencies managing old-age pensions; further audit of millions of individual income tax returns is no longer necessary. Since old-age pension benefits to pensioners are tax-free, filing income tax is not required even if pension benefits are received from several sources. This final advantage will not be reaped if not all pension savings vehicles are pre-taxed, although no mix of E-E-T and T-t-E taxation for different types of old-age pensions jeopardizes intertemporal neutrality or interpersonal equity.

\subsection{Deferred payment of front-loaded pension tax liabilities ${ }^{8}$}

A second policy option is to calculate the tax liabilities as they emerge but to postpone the payment of the accumulated notional tax liability until: (i) the individual leaves the country and no arrangements exist with the new residence country to continue postponing the payment till retirement when the tax liability becomes due; or (ii) the accumulated tax liability is turned into a tax annuity at retirement that must be paid to the tax administration in line with the pay-out of the monthly pension benefit.

Conceptually, such an approach is very much simplified if both unfunded and funded pensions are DC-type schemes in which at retirement the accumulated notional or actual amount of pension wealth is turned into an annuity using the same parameters; e.g. conditional cohort life expectancy. Then the accumulated amounts of net pension wealth, tax liability, and gross pension wealth are known and can be easily translated actuarially into the corresponding annuities.

Table 10 offers the calculations for an individual who initially earns $€ 12,000$ a year and contributes 20 percent to the pension scheme. His income is subject to an income (average/fixed) tax rate of 15 percent. We further assume that wages grow in line with the interest rate over an accumulation period of 45 years and a decumulation period of 25 years. For this pensioner, the gross replacement rate is 44.1 percent of last salary and his net replacement rate (net of deferred annuitized tax and pension contribution) is 55.1 percent.

\footnotetext{
${ }^{8}$ See Holzmann (2015) for details.
} 
Table 10: Deferred taxes and accumulated amounts (€)

\begin{tabular}{|c|c|c|c|c|c|c|c|c|c|}
\hline Year & Gross Earnings & $\begin{array}{r}\text { Annual } \\
\text { contribution }\end{array}$ & $\begin{array}{r}\text { Accumulated } \\
\text { (net) savings }\end{array}$ & $\begin{array}{r}\text { Interest } \\
\text { received }\end{array}$ & $\begin{array}{l}\text { Annual tax } \\
\text { (gross) due }\end{array}$ & $\begin{array}{r}\text { Annual } \\
\text { deferred tax }\end{array}$ & Deferred tax & $\begin{array}{r}\text { Interest on } \\
\text { deferred tax }\end{array}$ & $\begin{array}{l}\text { Accumulated } \\
\text { gross savings }\end{array}$ \\
\hline 1 & 12000 & 2400 & 2400 & 0 & 1800 & 360 & 360 & 0 & 2760 \\
\hline 2 & 12360 & 2472 & 4944 & 72 & 1854 & 371 & 742 & 11 & 5686 \\
\hline 3 & 12731 & 2546 & 7638 & 148 & 1910 & 382 & 1146 & 22 & 8784 \\
\hline 44 & 42774 & 8555 & 376413 & 10714 & 6416 & 1283 & 56462 & 1607 & 432875 \\
\hline 45 & 44057 & 8811 & 396517 & 11292 & 6609 & 1322 & 59478 & 1694 & 455994 \\
\hline $\begin{array}{r}\text { Annuity } \\
\text { (LE 25 y) }\end{array}$ & & & 15861 & & & & 2379 & & 18240 \\
\hline
\end{tabular}

What are the possible advantages of such a deferred tax payment policy option over the direct payment option proposed in section 4.2? Four considerations are offered:

First, the approach combines a formal front-loading of taxation (T-E-E) with a material back-loading (E-E-T), as the tax is only due when benefits are disbursed. Thus the economic incentive effects of expenditure taxation remain effective for scheme participation and savings decisions. This effect may be purely psychological and should not matter for a homo economicus acting in a perfect capital market without liquidity constraints, as the present values of the tax liability are identical. It may, however, matter politically as in comparison to prepaid taxes, deferred taxation should reduce the probability that tax policy is tempted to charge pension benefits again when benefits are paid out.

Second, while exit taxation on accumulated pension wealth upon migration meets resistance under the current EU ruling and is not addressed in most double taxation treaties, the payment of income tax liabilities upon migration should be accepted more easily. Furthermore, moving to a new country of residence before or after retirement need not trigger immediate payment of the tax liability but can be continued in line with the disbursement of the net annuity from the source country. Informing the new residence country about the gross and net annuity would allow tax authorities of the residence country to better assess the overall tax liability of the retiree as other local pensions and other income are likely to be added.

Third, the recording of deferred tax liabilities, taxes already paid, and the net amount of pension wealth across an individual's lifecycle should prove very useful by offering transparency on tax revenue claims, on tax payments, and thus on their distribution across individuals and groups. This is useful even in the absence of portability considerations but crucial to evaluate and audit fairness across individuals and countries.

Last but not least, the availability of aggregated data at national level would allow an easier assessment of gross versus net implicit public pension liabilities. By 2017, EU member countries will be required to publish data on (gross) implicit pension liabilities through SNA satellite accounts. Currently only gross liabilities are known (and one simple and dated country study on net liabilities 
from the early 1990s). The revenue content of pension claims/liabilities gains importance with aging populations.

\subsection{Split payment of front-loaded pension tax liabilities}

A natural extension of front- and back-loaded pension taxation as policy options is a tax payment mechanism where tax payments are spread across the whole lifecycle by charging the same "tax payment" rate on income spent on contributions, income through pension wealth returns, and benefit pay-outs. Conceptually this third policy option creates the same tax lability as option 1 and 2, but with a lower tax rate at each stage: Contribution payment, returns on pension assets, and benefit disbursement are taxed $t^{*}-t^{*}-t^{*}$, where $t^{*}$ is the tax rate on the periodical tax bases that generate the same net present value of pension taxes as the Fisher/Kaldor expenditure tax, either E-E-T or T-t-E.

Under the tax lability constraint, the tax rate $t *$ is an endogenous variable. With the values used in Table 10, we can calculate the tax rate on contributions, interest earned, and annuity disbursed (net of taxes already paid) that meets the tax liability constraint in present value terms. $t^{*}$ is 6.01 percent compared to a tax rate of 15.0 percent under both the front- and back-loaded approach. ${ }^{9}$ The rate $t^{*}$ changes with the length of accumulation periods compared to that of decumulation periods and with the level of interest rate compared to that of the growth rate. The longer the accumulation period relative to the decumulation period, and the higher the interest rate relative to the growth rate, the lower the split rate compared to the income tax rate. But the differences are small in relevant ranges.

What are the possible advantages of a $\mathrm{t}^{*}-\mathrm{t} * \mathrm{t} *$ regime compared to a E-E-T or T-t-E regime that constrains tax payment to the accumulation or decumulation stage? Three main considerations are relevant. First, $\mathrm{t} *$ is much lower than the income tax rate $\mathrm{T}$ because tax payments become due along the whole accumulation and decumulation phase of pension wealth. Although the present value of tax payments and therefore the lifetime income effect are the same, individuals may be induced to interpret $t^{*}$ as the relevant income tax rate in adjusting their intertemporal consumption behavior and to regard pension taxation as less distortive. Such an effect can result from the reduced liquidity constraints under a lower tax rate and phased tax payment.

Second, $t^{*}-t^{*}-t^{*}$ taxation should facilitate negotiations on fiscal fairness between countries under rising labor migration. For migrating workers, the pressure for any exit tax arrangement is reduced as some income taxes have already been paid in the old residence country. For migrating retirees, the new residence country has access to a substantial share of the overall tax lability - less than under a pure residence-based scheme (which is under attack) but more than under a front-loaded scheme.

\footnotetext{
${ }^{9}$ The shares of tax revenues for each stage (contribution, interests, and disbursement) are 38 percent, 26 percent, and 36 percent, respectively.
} 
Third, expanding the base for pension tax payments introduces a new tax angle for revisions of double taxation treaties. While the total tax burden is determined by national income tax codes, defining $t^{*}$ offers an additional instrument that allows allocation of revenue shares of income taxes paid by migrants among residence and source countries. It remains to be seen whether this new instrument will open a new dimension of double taxation treaty renegotiation. It requires not only adjusting national pension taxation but also further investigating the conceptual and empirical consequences of bilateral revenue sharing.

\section{Concluding Remarks}

The taxation of internationally portable pensions and other retirement savings is characterized by astonishing diversity, complexity, and inconsistency. This disarray reflects national autonomy in the taxation of retirement income but also room for specific bilateral rules in avoiding double taxation of different forms of old-age pensions. This conceptual and operational heterogeneity creates economic distortions and inequities among individual pensioners as well as fiscal distortions and revenue inequities between countries. In view of the rising share of individuals spending at least some part of their working life abroad and acquiring assets and pension rights in source countries away from their future retirement residency, the situation is unsustainable and must be corrected.

Addressing the issue requires a coordinated approach beyond bilateral tax treaties and an agreed general concept for the taxation of pensions that avoids or at least minimizes individual- and countrylevel distortions; neither benchmark for coordination is currently at hand.

To initiate discussion toward such a conceptual framework of portable pension taxation, this paper suggests three integrated policy options that build on existing policy thinking to facilitate consensus building. It also offers new perspectives that may help to overcome reform resistance. The three policy options are summarized as follows.

First, the approach supports an expenditure-type treatment of retirement savings but suggests a move from back-loaded taxation to alternative variants of front-loaded taxation. Generalized front-loaded taxes minimize distortions for individuals and facilitate fiscal equity between countries.

Second, the proposed policy options subject an individual to the same front-loaded tax liability in present value terms but differ in the timing of settlement. The three time profiles of settlement are: (i) immediate payment of tax liability in the period in which it is created; (ii) postponed settlement until pension wealth is dispersed and liquidated; and (iii) a symmetric splitting of tax payments across the whole cycle of pension accumulation and disbursement by charging the same "tax payment" rate on income spent on pension contributions, pension wealth returns, and decumulation through pension benefits. 
Third, implementation of any of these three tax policy options requires a multi-lateral approach, starting with, for example, a pan-European decision to move from back- to front-loading of tax liabilities, while the operational implementation can be left to a revision of bilateral agreements under the overall conceptual framework. Non-European countries would face strong pressure to replicate the approach to avoid revenue shortfalls and double taxation. And the resistance may be limited, as a number of non-European countries have already started a discussion about front-loading pension taxation. 


\section{References}

Allianz International Pensions. 2013. Allianz Country Factsheets 2013. Munich: Allianz SE.

Allianz International Pensions. 2015. Allianz Country Factsheets 2015. Munich: Allianz SE.

Atkinson, Anthony and Joseph Stiglitz. 1976. "The design of tax structure: direct versus indirect taxation.” Journal of Public Economics 6 (1-2): 55-75.

Auerbach, Alan. 2009. "Direction in Tax and Transfer Theory." in Melbourne Institute, ed. Australia's Future Tax and Transfer Policy Conference: Proceedings of a Conference, University of Melbourne, Chapter 4: 63-71.

Eurostat. 2015. Migration and Migrant Population Statistics. Eurostat Data Base.

Fisher, Irving. 1930. The Theory of Interest. New York: Macmillan

Genser, B. 2015. "Towards an International Tax Order for the Taxation of Retirement Income.” CEPAR Working Paper 2015/25. Sydney: University of New South Wales.

Holzmann, Robert. 2015. "Taxing Pensions of an Internationally Mobile Labor Force: Portability Issues and Taxation Options.” CEPAR Working Papers 2015/22. Sydney: University of New South Wales.

Huang, J. 2008. “Taxable and tax-deferred investing: a tax-arbitrage approach.” Review of Financial Studies 21(5): 2174-2207.

Institute for Fiscal Studies. 1978. The structure and reform of direct taxation. London: Allen and Unwin.

International Bureau of Fiscal Documentation (IBFD). 2015. European Tax Handbook 2015. Global Tax Series, IBFD, Amsterdam.

Kaldor, Nicholas. 1955. An Expenditure Tax. London: Allen and Unwin.

Mirrlees, J. 2010. Tax by Design - The Mirrlees Review. Oxford UP.

OECD. 2015. Pensions at a Glance 2015: OECD and G20 Indicators. Paris: OECD Publishing.

OECD Data: Pensions. https://data.oecd.org/pension

OECD. 2013. Action plan on base erosion and profit shifting. Paris: OECD Publishing.

OECD. 2015. Pension Funds in Figures. Paris: OECD Publishing, May.

Robalino, David, Edward Whitehouse, Anca Mataoanu, Alberto Musalem, Elisabeth Sherwood, and Oleksiy Sluchynsky. 2005. "Tax treatment of pension systems. In Pensions in the Middle East and North Africa. Time for change, pp. 211-216. Orientations in Development Series. Washington, D.C.: World Bank.

Towers Watson. 2015. Global Pension Asset Study 2015. February. www.towerswatson.com/en/Insights/IC-Types/Survey-Research-Results/2015/02/GlobalPensions-Asset-Study-2015

US Department of Treasury. 1977. Blueprints for basic tax reform. Washington, DC: US Government Printing Office.

Wellisch, D., S. Lorz, K. Thiele, and R. Gahl. 2008. Besteuerung der Altersvorsorge. Baden-Baden: Nomos.

Whitehouse, Edward. 1999. "The Tax Treatment of Funded Pensions.” Social Protection Discussion Paper Series No. 9910, April. Washington, DC: World Bank. 